\title{
A Note On Accounting For Employee Stock Options When Reporting Diluted Earnings Per Share Under The Treasury Stock Method
}

David T. Doran, Penn State - Erie, USA

\begin{abstract}
Firms must currently apply the fair value method in determining the amount of employee compensation incurred in the case of employee stock options. Current GAAP also requires that for purposes of calculating diluted earnings per share (EPS), the treasury stock method be applied where the assumed proceeds from exercise of the optioned shares is used to purchase shares of the firm's stock at its average market price of the earnings period. These incremental shares increase the denominator for purposes of calculating diluted EPS. These requirements are consistent across the pronouncements of the Financial Accounting Standards Board (FASB) and the International Accounting Standards Board (IASB). This study extends the work of Doran (2005) and Doran (2008). These previous studies found that applying the treasury stock method where shares are assumed purchased at the average for the period price (instead of end of year price) understates the number of incremental shares (the denominator), which overstates diluted EPS. However, these previous works assumed that no shares were actually purchased for the treasury during the earnings period. The FASB indicates one reason that the average for the period price is appropriate is because if treasury shares purchases were to occur, "the shares would be purchased at various prices, not at the price at the end of the period." This study tests the notion that the average for the period price is appropriate under circumstances where the firm actually purchases shares for the treasury at its average market price during the earnings period. This paper employs a simple one period model that assumes a risk free environment with complete certainty. The model allows comparison of computed EPS with an a priori known, correct amount. Consistent with Doran (2005) and Doran (2008), the results here again indicate that assuming purchase of treasury shares at their average market price of the earnings period understates the EPS denominator which results in EPS overstatement. Correct diluted EPS is derived when the shares assumed purchased under the treasury stock method are acquired at the higher period ending market price.
\end{abstract}

Keywords: Diluted EPS, Employee Stock Options, Treasury Stock Method.

\section{INTRODUCTION}

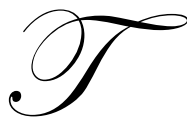

he Financial Accounting Standards Board (FASB) issued a revised Statement No. 123 (SFAS No. 123R) in December 2004 that requires the fair value method of accounting for employee stock options. The International Accounting Standards Board (IASB) likewise requires the fair value method in International Financial Reporting Standard (IFRS) No. 2.

Also, in the case of outstanding stock options, diluted earnings per share calculations require that the treasury stock method be applied if the affect is dilutive. This method assumes all options are exercised at the beginning of the period (or date of grant if issued during the period). The proceeds from this assumed issuance are 
used to purchase shares of the firm's stock for the treasury. If the option price is less than the reacquisition price, more shares will be assumed issued than are assumed purchased for the treasury. This difference represents "incremental shares" that are added to the denominator of the EPS calculation with a resulting dilution. Previously under US GAAP, the number of incremental shares was determined under APB No. 15, but was superceded by SFAS No. 128 which states: "The Board made one change to the treasury stock method prescribed in Opinion 15. This Statement requires that the average stock price for the period always be used in determining the number of treasury shares assumed purchased with the proceeds from the exercise of options or warrants rather than the higher of the average or ending stock price as prescribed by Opinion 15. The Board believes that use of the average stock price is consistent with the objective of diluted EPS to measure earnings per share for the period based on period information and that use of end-of-period data or estimates of the future is inconsistent with that objective. If purchases of treasury shares actually were to occur, the shares would be purchased at various prices, not at the price at the end of the period. In addition, use of an average stock price eliminates the concern that end-of-period fluctuations in stock prices could have an undue effect on diluted EPS if an end-of-period stock price were required to be used." The IASB also requires that the number of incremental shares be calculated by assuming purchase at average for the period price, "The difference between the number of ordinary shares issued and the number of ordinary shares that would have been issued at the average market price of ordinary shares during the period shall be treated as an issue of shares for no consideration". ${ }^{2}$

\section{PURPOSE OF STUDY AND METHODOLOGY}

This study extends the efforts of Doran (2005) and Doran (2008) that tested the accuracy of diluted EPS in the case of employee stock options. Both these studies found that applying the treasury stock method where shares are assumed purchased at the average for the period price (instead of at the higher end of year price) understates the number of incremental shares (the denominator), which overstates diluted EPS. This study extends the work of Doran (2005) and Doran (2008) by analyzing diluted EPS accuracy in accounting for employee stock options while assuming shares are actually purchased for the treasury at the average for the period price. This tests the FASB's notion that the average for the period price is appropriate because, "If purchases of treasury shares actually were to occur, the shares would be purchased at various prices, not at the price at the end of the period."

A simple one-period model that assumes complete certainty is developed. The fair value of employee compensation is given, and the complete certainty assumption indicates that the employee and the firm should be economically indifferent to various compensation schemes (including cash transfer or stock option grant). Given the assumptions of the model, the true amount of EPS is "known" and should be observed regardless of the compensation scheme assumed. Initially EPS is calculated under the cash compensation scenario. Although EPS derived for the year is somewhat misstated, the error is attributed to the weighted average technique required under SFAS 128 to determine the denominator in situations where the number of shares outstanding changes during the earnings period.. When EPS is derived based upon the sum of the year's interim EPS amounts, the "known" EPS is observed. Diluted EPS is then calculated assuming the stock option scenario. If current GAAP is appropriate, the "known amount of diluted EPS" should again be derived where treasury stock is assumed acquired at the average for the period price. The results indicate diluted EPS is overstated when the average for the period price is used under the treasury stock method. The "known" diluted EPS amount is derived only when the higher year end price is used.

\section{MODEL}

The analysis is based upon various compensation schemes by a firm for an employee who renders services to the firm worth $\$ 1$ million at the beginning of the one year time horizon. This simple one period model includes the following assumptions:

1. There is no risk, and all entities earn an available $10 \%$ annual risk free rate of return.

2. There are no dividends, taxes, or transaction costs.

\footnotetext{
${ }^{1}$ Statement of Financial Accounting Standards No. 128 (February 1997) Paragraph 107.

${ }^{2}$ International Accounting Standard No. 33, (2006) Paragraph 45.
} 
3. The book value of the firm is $\$ 220$ million at $1 / 1 / 01$.

4. The firm has 10 million shares of stock outstanding at $1 / 1 / 01$ and the market value per share is $\$ 22$, the total market value of the firm is $\$ 220$ million.

5. If a stock option is used as compensation, it vests immediately, is fully transferable, and if employee terminates employment prior to the one year option term, $\mathrm{s}(\mathrm{he})$ must exercise immediately.

The FASB indicates that firms generally set the option price at least at the stock's market value on the grant date, and in doing so avoid creating any intrinsic value. This minimum option price would result in granting an option to buy $500 \mathrm{k}$ shares at $\$ 22$ per share.

Under the assumptions of the model, all participants are certain that the market value of the stock in one year (1/1/02) will be $\$ 24.20$ per share. With that being the case, the employee and the firm should be indifferent between compensation packages of:

a. Compensation of $\$ 1$ million cash paid on 1/1/01,

b. Granting the employee an option to purchase 500,000 shares of the firm's stock for $\$ 22.00$ per share for a term of 1 year (see assumption 5 above).

Given the economic equivalence of the cash payment vs. the stock option compensation scenarios, earnings per share should be consistent across these alternatives. Derived EPS should be $10 \%$ of the 1/1/01 value of the stock $(10 \% * \$ 22$ per share) providing the "known" amount of EPS for year 01 of $\$ 2.20$.

The model also assumes that the firm actually reacquires 500,000 shares for the treasury on 7/1/01. With an annual return of $10 \%$, the market price of the stock on $7 / 1 / 01$ would be approximately $\$ 23.07$ per share $(\$ 22 * \sqrt[2]{1.1})$. The total acquisition cost of the shares is $\$ 11,536.897(500,000$ shares $@ \$ 23.07$ per share). This acquisition reduces outstanding shares for the 7/1/01 - 12/31/01 period to 9,500,000 shares and reduces income by the foregone profit in the amount of $\$ 563,103(\$ 11,536,897 *(\sqrt[n]{1.1})-1))$ for this second half of the year.

\section{RESULTS}

Table one provides the GAAP based calculation of EPS in the case of the employee receiving cash compensation. Panel A shows EPS for the entire year under GAAP. The computed EPS is slightly less than the "known" amount of $\$ 2.20$. Panel B derives the correct, known amount by considering each six month period separately, and summing the two. Earnings for the first six month period is correctly computed as: $\$ 22 *((\sqrt[2]{1.1})-1))$ $=1.07379466$. EPS for the last six month period is also correctly computed as: $\$ 23.07379466 *((\sqrt[2]{1.1})-1))=$ $\$ 1.12620534$. The sum of these two semiannual EPS amounts $=\$ 2.20$. EPS computed for the entire year may not equal the sum of interim EPS when the number of shares outstanding changes during the year. Only if the change in earnings (the numerator) is proportionate to the change in shares outstanding (the denominator) will the two be equal. The issue of annual EPS not equaling the sum of the interim EPS amounts for the period is illustrated in SFAS $128^{3}$.

Tables two and three provide the calculations of EPS under the stock option compensation scheme. Contrary to GAAP, Table two assumes shares are purchased under the treasury stock method at the higher year end price, while Table three, consistent with GAAP, assumes the shares are purchased at the average price for the year price. Net income is $\$ 100,000$ higher in the case of the stock option compensation scenario. This increased income is attributed to the additional cash ( $\$ 1$ million) being retained by the firm at the beginning of the year and invested to earn the risk free annual rate of $10 \%$.

\footnotetext{
${ }^{3}$ See SFAS 128 Par. 150.
} 
Table 1: Cash Compensation

Employee Receives \$1,000,000 Cash on 1/1/01

Panel A: Full Year Diluted EPS

Income before compensation and Foregone Profit
$\$ 23,000,000$
$1,000,000$
$\underline{563,103}$
$\$ 21,436,897$
$9,750,000$
$\$ 2.19865614$

Foregone Profit

Net income

Weighted Average Shares Outstanding

Earnings per share

Panel B: Reconciliation to Known EPS

\begin{tabular}{lrr} 
& $1 / 1 /-6 / 30 / 01$ & $7 / 1-12 / 31 / 01$ \\
Income before compensation and Foregone Profit & $\$ 11,237,947$ & $\$ 11,762,053$ \\
Compensation expense & 500,000 & 500,000 \\
Foregone Profit & $-0-$ & 563,103 \\
Net income & $\$ 10,737,947$ & $\$ 10,698,950$ \\
Weighted Average Shares Outstanding & $10,000,000$ & $9,500,000$ \\
Earnings per share & $\$ 1.07379466$ & $\$ 1.12620534$ \\
Earnings per share for year 01 (sum of 2 semiannual EPS) & $\$ 2.20$ & \\
\hline
\end{tabular}

Table 2: Stock Option Compensation

Assume Shares Purchased For Treasury At Year End Price Employee Receives Option to Purchase 500,000 Shares at \$22 per Share

Panel A: Full Year Diluted EPS

Income before compensation and Foregone Profit
$\$ 23,100,000$
$1,000,000$
$\underline{563,103}$

Compensation expense

Net income (Same as Above)

$\$ 21,436,897$

Weighted Average Shares Actually Outstanding

Incremental Shares Assumed - Treasury Stock Method

$9,750,000$

Total Shares Assumed Outstanding Diluted EPS

45,456

$9,795,456$

Earnings per share

$\$ 2.19866237$

\section{Panel B: Reconciliation to Known EPS}

Income before compensation and Foregone Profit

\begin{tabular}{rr}
$1 / 1 /-6 / 30 / 01$ & $7 / 1-12 / 31 / 01$ \\
$\$ 11,286,755$ & $\$ 11,813,245$ \\
500,000 & 500,000 \\
$-0-$ & 563,103 \\
\hline$\$ 10,786,755$ & $\$ 10,750,142$ \\
& $9,500,000$ \\
$10,000,000$ & 45,455 \\
45,455 & $9,545,455$ \\
\hline $10,045,455$ & $\$ 1.12620534$ \\
$\$ 1.07379466$ & \\
$\$ 2.20$ &
\end{tabular}

Earnings per share for year 01 (sum of 2 semiannual EPS)

Foregone Profit

Net income

Weighted Average Shares Actually Outstanding Incremental Shares Assumed - Treasury Stock Method

Total Shares Assumed Outstanding Diluted EPS

Earnings per share 
Panel A from Table two indicates that annual EPS is somewhat understated relative to the "known" amount. This is consistent with the observed understated annual EPS under the cash compensation scheme depicted in Table one. Panel B indicates that again, consistent with the cash compensation scenario, EPS for each six month period is correct, and their sum is equal to the "known" amount $(\$ 2.20)$.

Table 3: Stock Option Compensation Assume Shares Purchased For Treasury At Average Price

\section{Panel A: Full Year Diluted EPS}

Income before compensation and Foregone Profit

Compensation expense

Foregone Profit

Net income

Weighted Average Shares Actually Outstanding Incremental Shares Assumed - Treasury Stock Method

Total Shares Assumed Outstanding Diluted EPS

Earnings per share

$$
\begin{array}{r}
\$ 23,100,000 \\
1,000,000 \\
563,103 \\
\$ 21,436,897 \\
9,750,000 \\
23,269 \\
\hline 9,773,269
\end{array}
$$

$\$ 2.20365345$

\section{Panel B: Reconciliation to Known EPS}

\begin{tabular}{lrr} 
& $1 / 1 /-6 / 30 / 01$ & $7 / 1-12 / 31 / 01$ \\
Income before compensation and Foregone Profit & $\$ 11,286,755$ & $\$ 11,813,245$ \\
Compensation expense & 500,000 & 500,000 \\
Foregone Profit & $-0-$ & 563,103 \\
Net income & $\$ 10,786,755$ & $\$ 10,750,142$ \\
& $10,000,000$ & $9,500,000$ \\
Weighted Average Shares Actually Outstanding & 23,269 & 23,269 \\
\cline { 2 - 3 } $\begin{array}{l}\text { Incremental Shares Assumed - Treasury Stock Method } \\
\text { Total Shares Assumed Outstanding Diluted EPS } \\
\text { Earnings per share }\end{array}$ & $10,023,269$ & $9,523,269$ \\
& $\$ 1.07617143$ & $\$ 1.128829$ \\
Earnings per share for year 01 (sum of 2 semiannual EPS) & $\$ 2.20500043$ &
\end{tabular}

Table three indicates that contrary to the previously discussed annual EPS amounts, when the average for the period price is used for assumed purchases of shares under the treasury stock method, overstatement is observed. When EPS are calculated for the individual six month periods, they are also found to be overstated relative to the correct "known" amounts. When added together the interim amounts actually increase the overstatement of EPS rather than reconciling to the known annual amount $(\$ 2.20)$.

\section{CONCLUSION}

As can be seen from Table 3 (Panel A and B), GAAP compliant calculated EPS is consistently overstated under US and IASB standards. The known amounts of correct EPS are derived only when the shares purchased for the treasury are assumed acquired at the higher year-end price. These results support the findings in Doran (2005) and Doran (2008). If firms actually acquire shares for the treasury throughout the earnings' period, it has no bearing on the notion that the average for the period price is appropriate when applying the treasury stock method. Justification for using the average for the period market price for purposes of calculating incremental shares is provided by the FASB in SFAS No. 128: "This Statement requires that the average stock price for the period always be used in determining the number of treasury shares assumed purchased with the proceeds from the exercise of options or warrants rather than the higher of the average or ending stock price as prescribed by Opinion 15 . The 
Board believes that use of the average stock price is consistent with the objective of diluted EPS to measure earnings per share for the period based on period information and that use of end-of-period data or estimates of the future is inconsistent with that objective. If purchases of treasury shares actually were to occur, the shares would be purchased at various prices, not at the price at the end of the period". ${ }^{4}$

The FASB may want to reconsider previous GAAP under APB No. 15 that required using the higher yearend price when applying the treasury stock method in calculating diluted EPS in the case of employee stock options.

\section{AUTHOR INFORMATION}

David T. Doran. Upon receiving an undergraduate degree with a major in accounting, David T. Doran was employed by the "big eight" public accounting firm of Coopers \& Lybrand. He is currently licensed to practice as a $\mathrm{CPA}$ in Pennsylvania. Professor Doran earned his MBA and PhD degrees from the University of Pittsburgh and has been teaching at Penn State - Erie since 1989. His primary research interests are in the financial accounting area, which is consistent with his main teaching responsibilities - intermediate and advanced financial accounting.

\section{REFERENCES}

1. Accounting Principles Board, Opinion No. 15, "Earnings per Share", May 1969.

2. Doran, D.T., "Employee Stock Options and Diluted EPS," Journal of Business and Economics Research, Vol. 3, No. 11, 2005, pp 51-56.

3. Doran, D.T., "Employee Stock Options and Diluted EPS: An Extension," International Business and Economics Research Journal, Vol. 7, No. 2, 2008, pp 25-31.

4. Financial Accounting Standards Board, Statement of Financial Accounting Standards No. 128, "Earnings per Share", February 1997.

5. Financial Accounting Standards Board, Statement of Financial Accounting Standards No. 123 (revised 2004), "Share-Based Payment”, December 2004.

6. International Accounting Standards Board, International Financial Reporting Standard No. 2, "Share Based Payment", The full text of all International Financial Reporting Standards extant at January 1, 2006.

7. International Accounting Standards Committee, International Accounting Standard No. 33, "Earnings per Share", The full text of all International Financial Reporting Standards extant at January 1, 2006.

\footnotetext{
${ }^{4}$ Statement of Financial Accounting Standards No. 128 (February 1997) Paragraph 107.
} 